\title{
SiM
}

\section{Optimum Stocking Rate, Monitoring, and Flexibility}

\section{Key components of successful grazing management programs}

\author{
By J. Alfonso Ortega-S., Steven D. Lukefahr, and Fred C. Bryant
}

\section{On the Ground}

- This case study demonstrates the importance of adaptive management to the resilience of a ranch.

- With a combination of strategic livestock and grazing management, especially adjusting the stocking rate to variability in forage production, we were able to increase the grazing capacity and the profitability of the ranch, even during drought.

- The major concern during the drought should not be the productivity or profitability of the ranch, but rather the integrity of the plant communities and the herd in order to re-establish the production cycle following the severe drought.

- Managing flexible grazing management programs with proper monitoring of weather, forage standing crop, cattle condition, and markets to make informed and timely decisions largely determines the resilience and profitability of the operation.

Keywords: grazing management, ranch profitability, optimum stocking rate, flexible grazing, monitoring.

Rangelands 35(5):22-27

doi: 10.2111/RANGELANDS-D-13-00021.1

(C) 2013 The Society for Range Management

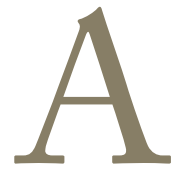

s Frank Price stated in describing his 30-year grazing program, "The biggest problem for me is that I can never come up with a grazing plan that I can stay with-I am continually changing grazing rotations, time, and stock numbers... But that is one of the reasons that this program works. It is not a system. It is a continually changing program that moves with the weather, livestock, and markets." 1 The concept of strategically managing a flexible stocking rate and monitoring range and animal responses to adapt to changing conditions is not new; as a matter of fact, academicians and extension agents have published in- formation and made recommendations for decades. However, in most cases practitioners have a hard time applying these recommendations. A Google search using the words "determining proper stocking rate" yielded 10 million results and "determining carrying capacity" over 30 million results, providing an idea of how often this concept has been discussed. Methods to calculate correct stocking rate are also available in rangeland texts and extension publications. Similarly, published scientific and popular articles with recommendations and benefits of managing rangeland at "proper" or "moderate" stocking rate in different environments are very easy to find. However, it is difficult to manage ranches using a single "correct" stocking rate for rangelands characterized by variable rainfall patterns; it is a moving target, is dynamic in time and space, and is affected by climatic factors that we cannot control.

The first step in successful ranching is developing clear goals and objectives because the grazing program must be part of the overall management strategy (see Provenza et al., this issue). Development of a grazing management program must consider enough flexibility to respond to environmental variations, as well as livestock requirements and market opportunities. In this context, we illustrate the art and science of combining critical components of grazing management to preserve the integrity and productivity of pastures, optimizing biological and economical outputs from livestock.

\section{Stocking Rate}

Stocking rate is the most important factor affecting the results of a grazing management program., ${ }^{2,3}$ The relationships between stocking rate and animal performance and production per unit area have been documented ${ }^{4}$ after considering 25 North American stocking rate studies. The economic optimum stocking rate will be higher than the rate that maximizes production per head, and lower than the rate that maximizes production per acre (see Frasier and Steffens, this issue). However, the limited ability to monitor and predict forage production and availability and to relate it to carrying capacity and animal production is a major management limita- 
tion. ${ }^{3}$ This situation often leads to overgrazing and decreased productivity and profitability of livestock operations. In many cases, a reduction in stocking rate on ranches that have been abused can increase calving and weaning rates and weaning weights, and decrease costs. The result can be a long-term increase in profitability of the operation, as documented by case studies in northern Mexico and south Texas. ${ }^{5,6}$

To illustrate the effects of stocking rate, we use a case study of a small cattle operation in south Texas. South Texas is a region where, in terms of precipitation, an abnormal year is probably the most normal condition-drought and flooding are common events. An analysis of 42 years of rainfall data from Kingsville, Texas indicated that between 1950 and 1997, 38\% of years were characterized by drought. ${ }^{7}$ However, there is a difference between drought and devastating drought. Between October 2008 and June 2009, only about 3 inches of rainfall was received, and by August 24, 2009, total rainfall was only $20 \%$ of the normal cumulative total (only 3.7 inches for the year, Fig. 1). Prior to 2009, the most recent serious drought between the October and June period occurred in 1952 and 1953 when precipitation was 6.6 inches, which was about $30 \%$ more than what was received in $2009 .{ }^{8}$ For 2011 and 2012, the situation was even worse. From October 2010 to January 2012, over a 15-month period, we received less than 10 inches of rainfall; from February to May, we received less than 3 inches, and from June to August less than 1 inch. Altogether, from October 2010 to August 2012, a 22-month period, we had less than 15 inches of rain, way below the regional long-term average of 22 inches (Fig. 1).

Our enterprise consisted of approximately 50 cows and breeding heifers on about 450 acres of native grasses mixed with Kleberg bluestem (Bothriochloa ischaemum) and bermudagrass (Cynodon dactylon). Crossbred cows were comprised of Red Angus, Senepol, and Tuli breeds (via rotational crossbreeding), the latter two breeds noted for heat and drought tolerance. Stocking rate was reduced from 1 animal unit (AU) per 3.4 acre in 2001 to at least $1 \mathrm{AU}$ per 5.7 acres in most of the years from 2003 to 2012, a reduction of over 40\% (Table 1). Forage is stockpiled in pastures following rains. Pastures are never fertilized or aerated. Cattle are rotated to the pasture in better condition in terms of quantity and quality. We rotate three to four cattle herds in 30 pastures of different sizes (5 to 85 acres) with grazing periods from 2 weeks to 3 months and rest periods from 5 weeks to 3 months, depending on pasture conditions, to use approximately $50 \%$ of forage standing crop during the spring and summer growing season. In some cases we have had pastures rested for a full year to allow recovery. In years with acceptable rainfall (please note that we are not using "average" or "normal" years, because that does not apply to south Texas), when we get 5 to 6 inches of rainfall properly distributed from January to May, we stockpile forage for winter grazing and in anticipation of spring and summer drought during the following year.

Cattle have not been fed hay or cereal grains in over 10 years. Calves are weaned following fall rains so that cows can recoup body condition before winter to minimize need of feed supplements. In severe droughts, an energy-protein supplement is provided (whole cottonseed). Most heifers are retained for breeding. Bull and remaining heifer calves are mostly sold for breeding to local ranchers. Calves not sold for breeding are mostly sold to partners who operate a grassfinished enterprise.

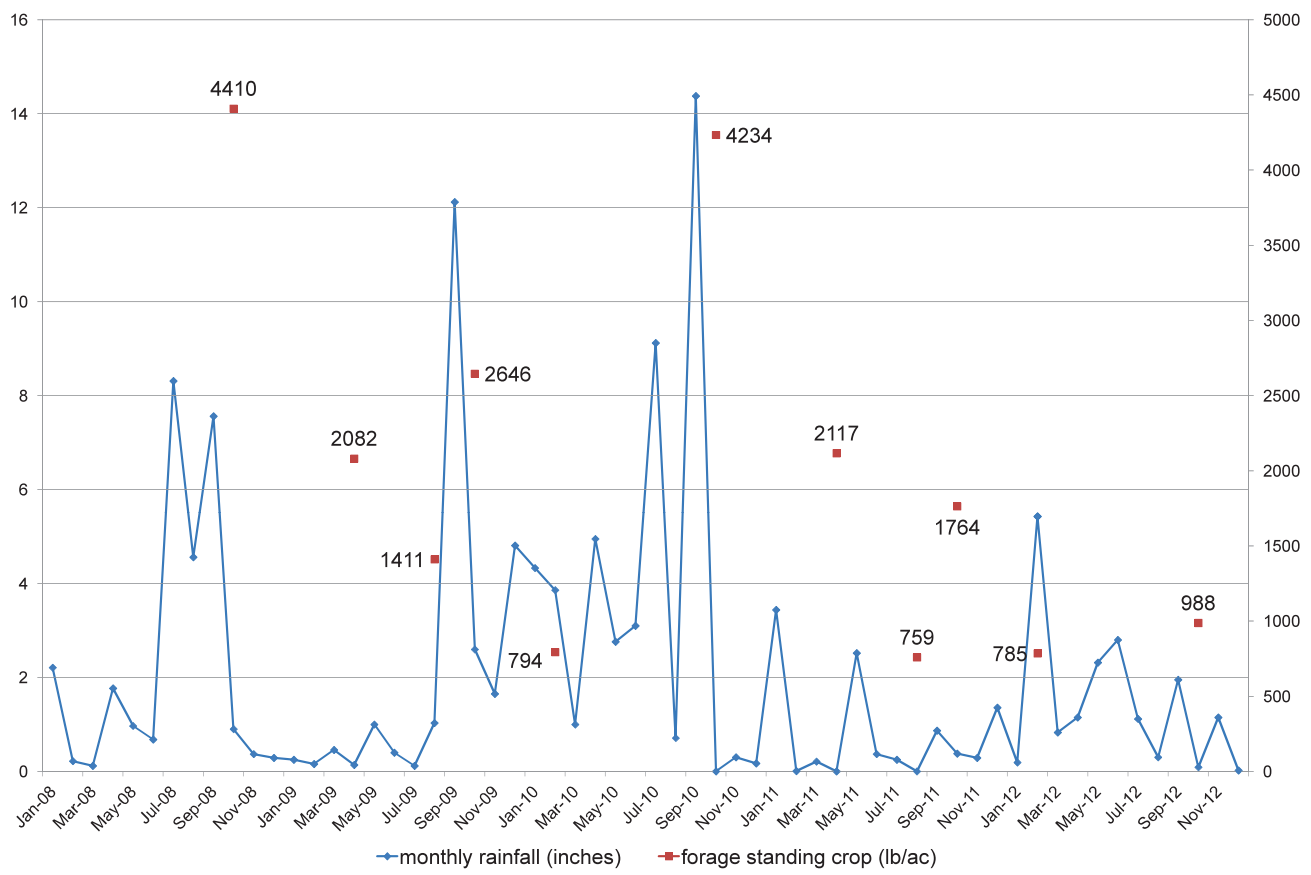

Figure 1. Forage standing crop from October 2008 to October 2012 when the two major droughts of the last 10 years occurred, plotted along with monthly rainfall for Kingsville, TX (2008-2012). 


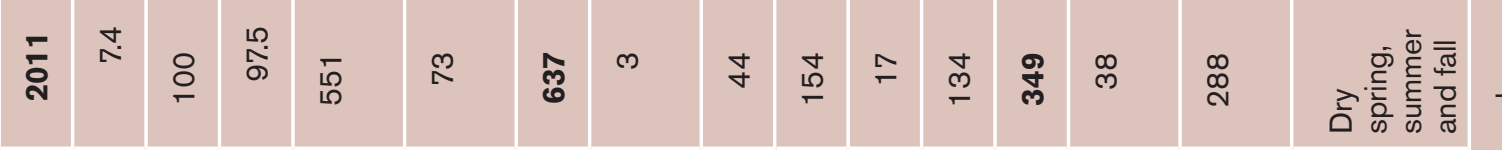

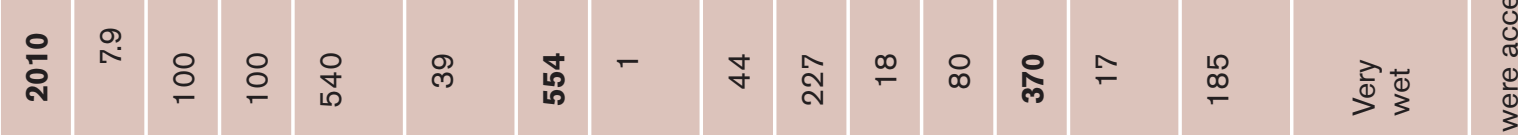

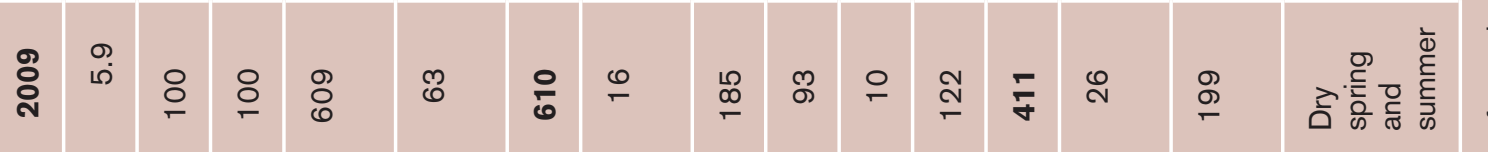

专

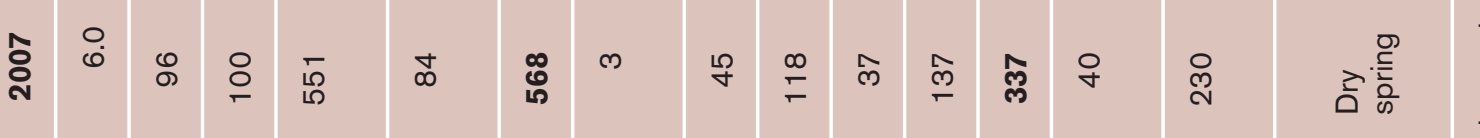

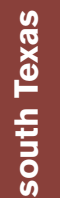

:

衁

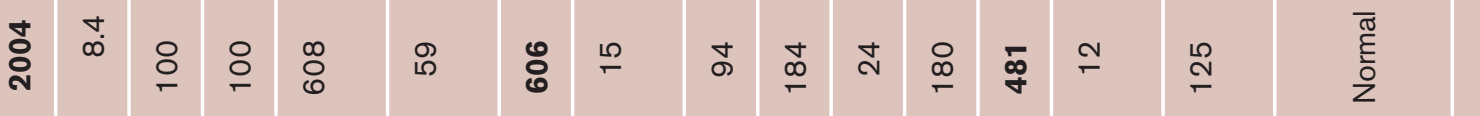

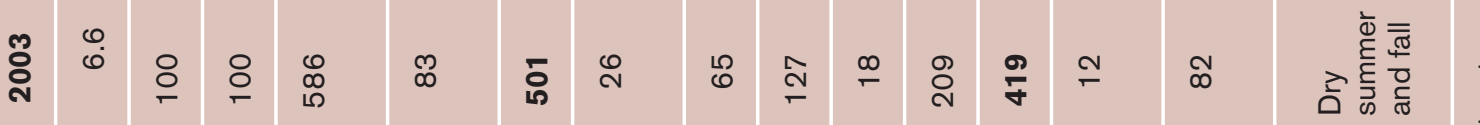

䒽

\begin{tabular}{|l|l|l|l|l|l|l|l|}
\hline & & & & & & & \\
\hline
\end{tabular}

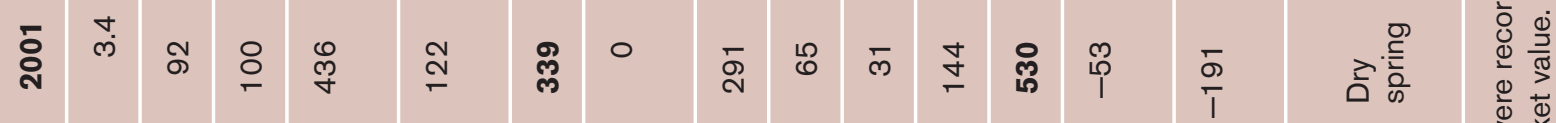

\begin{tabular}{|c|c|c|c|c|c|c|c|c|c|c|c|c|c|c|c|c|}
\hline $\boldsymbol{N}$ & & 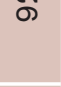 & 우 & $\stackrel{m}{q}$ & ลิ & ల్ల & & N & 0 & ल & $\stackrel{g}{\sim}$ & 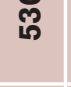 & i. & Tे & के & 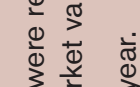 \\
\hline$\underline{\underline{\underline{\Phi}}}$ & 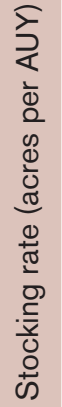 & 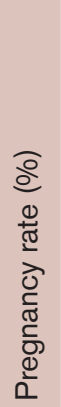 & 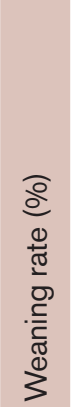 & 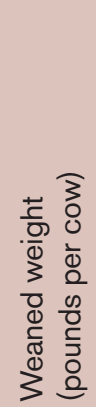 & 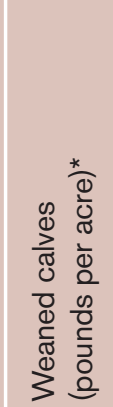 & 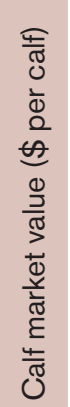 & 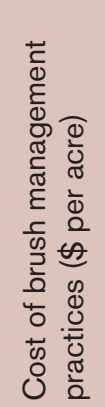 & 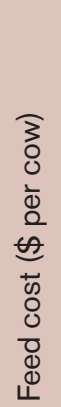 & 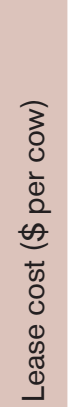 & 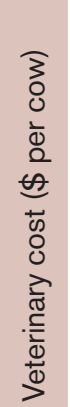 & 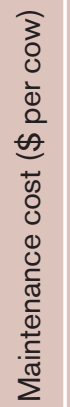 & 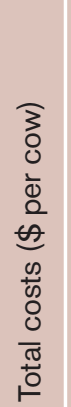 & 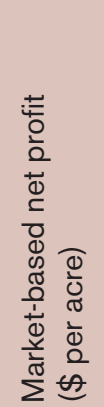 & 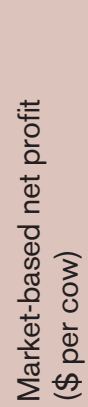 & 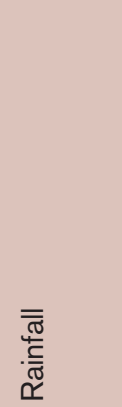 & 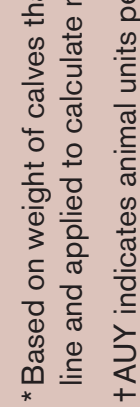 \\
\hline
\end{tabular}


The drastic reduction in stocking rate allowed us to avoid the traditional practice of feeding hay (which had represented 55 and $41 \%$ of the total business costs in 2001 and 2002, respectively; Table 1). It is important to notice that even in the extremely dry year of 2011, feed cost was only $\$ 44$ as compared to $\$ 291$ per cow per year in 2001 . Weaning weight increased from 436 pounds in 2001 to a range of 511 to 609 pounds from 2002 to 2011. Currently, foliar grass cover in all pastures is over $80 \%$. Even in the droughts of 2009 and 2011-2012, reproductive and productive parameters have been maintained in the operation. We believe one reason for this result is the conservative stocking rate we have used since 2002 (Table 1).

\section{Monitoring and Flexibility}

The importance of a flexible grazing program to achieve specific goals has been pointed out by different authors; ${ }^{7,9-11}$ however, it is difficult to determine positive or negative changes without data. Monitoring is a basic tool used to identify changes in pasture and cattle conditions. The ability to make timely decisions, which drives flexibility of the grazing program, can be greatly improved with a proper monitoring program. For grazing management purposes, we are interested in maintaining the integrity of pastures concurrently with the quantity and quality of the forage standing crop (FSC). Kothmann ${ }^{1}$ suggests "Ranchers evaluate the success of a grazing management program within the context of total system performance and goals, not just plant and animal production in response to fixed grazing treatments." We are interested in maintaining our pastures and cattle in good condition, but we are in this as a business; therefore, we also monitor cattle markets very carefully.

We monitor rainfall. Every year we expect to have 5 to 6 inches of accumulated rainfall from January to May with a proper distribution, and FSC by June should be at least 2,200 pounds per acre; if these two conditions are not met, stocking rate adjustments are triggered. We monitor FSC with a combination of visual estimations and hand clippings. Our goal is to use about $50 \%$ of the FSC and to maintain at least 750 pounds per acre of residual forage during drought (Fig. 1). Lactating cows and replacement heifers use the best pastures available. Nutritive value of forage is estimated visually; however, at least once per year we take samples to the lab to determine crude protein content. When evaluating forage nutritive value, we also estimate crude protein of the diet that cattle are consuming using the cow pie (fecal) assessment method. ${ }^{12}$

Cattle body condition scores $(\mathrm{BCS})^{13}$ also are monitored at least every month when FSC is below 2,000 pounds per acre. Our goal was to maintain each mother cow's BCS at a minimum of 5 . In rare cases, if a few cows are losing condition and they are about 4.5 BCS, they are moved to another pasture to be supplemented separately. These cows are good candidates for culling because they are not easy keepers.

Stocking rate decisions are based on rainfall, FSC, and markets. For example, in May 2013 we were about 2 inches below the average accumulated rainfall from January to May after two very dry years (2011 and 2012), and we had an average FSC of 1,200 pounds per acre. The market value for replacement heifers was high, and so we made the decision to sell 10 replacement heifers that we had kept from the 2012 calf crop to replace the mother cows we had sold during the drought. We decided to maintain only a core herd of mother cows because the rainfall was very limited and FSC was about 1,000 pounds per acre below our 2,200 pounds per acre target for the month of June. At this point we knew that even if moisture conditions were proper for the fall growth season (September-October) we would have only the 1,200 pounds per acre forage we had in June, plus at most $27 \%$ increased forage growth potential. This meant a maximum of 1,600 pounds per acre was all the forage we would have available until March of the following year, to begin the 2014 spring growth season if proper moisture became available - well below our targeted FSC.

\section{Coping with Low Forage Availability and Quality}

Nutritive value of stockpiled forage decreased considerably during the drought of 2009. In April, crude protein of sampled forage was only 4.54\%. Energy and protein supplementation to cattle began in March 2009 as we monitored the decrease in nutritive value of stockpiled forage in addition to BCS in cows. From March through August 2009, whole cottonseed ( $20 \%$ crude protein) and range cubes (37\% crude protein) were fed regularly to provide a minimum of approximately $0.5 \mathrm{~kg}$ of protein and $0.5 \mathrm{~kg}$ of fat for energy per cow per day. The timely decision to initiate the supplementation program was effective. By August 2009 at the end of the drought, body condition scores were maintained at over 5 with an average of $5.5 \pm 0.15$ (range of 4.5 to 7 ). By the end of February 2010, mean body condition scores increased to $6.8 \pm 0.13$ (range of 6 to 7.5). Even after a further reduction of forage quantity and quality caused by armyworms (Spodoptera frugiperda), cows were able to gain BCS at the end of the drought in the fall and winter without any feed supplements (except minerals). Feed-related expenses per cow increased from $\$ 41$ in 2008 to $\$ 185$ in 2009, a 351\% increase. However, there was no need to feed hay or destock cows; the moderate stocking rate and the practice of stockpiling forage proved to be effective to minimize the negative effects of the drought.

In the drought of 2011-2012 protein supplementation was needed for short periods of time. To maintain BCS between November and February, cottonseed cubes were fed intermittingly when conditions became dry and there was no green-up (total of 25.9 pounds per cow at a cost of $\$ 6.98$ per head for the winter). Generally, and even when mother cows were lactating, BCS seldom fell below 4.5. At the end of September 2012, we had 2 inches of rain and pastures started greening up nicely. However, after 22 months of drought, we made the decision to reduce stocking rate by about $60 \%$ to allow plants to recover from drought for the last 30 or 40 days of the growing season. At that point we had about 1,000 pounds per acre of standing forage; however, we needed that biomass to build up plant reserves and roots. 
In the last week of September 2012, we began our drought recovery plan. The first action taken was to cull eight cows (about 15\% of the herd; older cows or those with fertility issues). These cows might have been retained in the herd under different conditions; however, at this point allowing pastures to recover was a priority. Additionally, all calves over 300 pounds were weaned early to allow cows to gain BCS for the winter. Secondly, we began moving mother cows to previously and newly leased pastures. Here, the intent was to vacate or dramatically reduce stocking (about $80 \%$ reduction) on at least 200 acre (about $50 \%$ of the operation) to spur recovery.

The major concern during the drought should not be the productivity or profitability of the ranch, but rather the integrity of the plant communities and the herd in order to reestablish the production cycle following the severe drought. One of the main decisions the rancher needs to make is when and by how much to destock. Also, what are the criteria that should trigger the destocking process? If the decision of when to destock is made too late, the integrity of plant communities is affected and their capacity to recover after the end of the drought could be greatly diminished.

\section{Coping with High Forage Availability}

High forage availability is a good situation to have. In the unusually wet year of 2010, after a careful evaluation of the forage resources, we decided to keep all weanlings from that year for an additional 4 months. In this period of time, average weight gains were 54 pounds per animal and we obtained an additional profit of $\$ 42$ per head. Additionally, in December 2010 we bought 20 stockers: 10 heifers and 10 steers. We retained the steers for 4 months for an average weight gain of 67 pounds per animal and a net profit of $\$ 35$ per head. The heifers were kept for 6 months, gaining 126 pounds per animal and a net profit of $\$ 103$ per head. In both cases, we closely monitored the market and we made the decision to sell when the market price was at least 10 cents higher per pound than the buying price. This is not what usually happens, but in this case closely monitoring forage availability, animal performance, and the market allowed us to make timely decisions to optimize profits.

\section{Mother Nature Provides Pointers and Signs, But It Is Up to Us to Interpret Them}

In south Texas about $43 \%$ of the forage production occurs in March, April, and May, and 26\% in September and October; ${ }^{14}$ only $31 \%$ occurs in the remaining 7 months of the year. In a drought-prone environment such as south Texas, planning grazing management should consider the most critical times of the year. ${ }^{8}$, which are January to June and August to October. When we have a dry spring, we know beforehand that we missed most of the forage production potential for the season; it does not matter if we get sufficient rainfall in September.

During the drought of 2009, we received over 10 inches of rain in September. However, FSC at the end of October was only 2,646 pounds per acre compared to the 4,410 pounds per acre that we had in 2008 when we had good moisture in the spring. In this case, the monitoring program allowed us to identify a reduction in FSC compared to the previous year. At this point we made the decision to lease 100 acre more to overcome the shortage of forage. This decision proved to be appropriate. By February 2010, stockpiled forage was only 794 pounds per acre.

It is imperative to point out that after the end of the serious 2009 drought, and after receiving only limited moisture, pastures again looked green and lush. At that point we were already planning ahead. Notably, we started searching for land to lease almost 3 months before reaching the limit of 750 pounds per acre of residual forage. In this region, the standing forage you have at the end of October is what will be available for grazing until the beginning of the spring, a period of about 5 months. Monitoring rainfall distribution and FSC provide useful information to make timely decisions to make it work.

\section{Making It Work to Achieve Goals}

The practitioner should be able to manage the correct cattle stocking rate in a grazing program by allowing for enough flexibility to make necessary adjustments in droughts by using a monitoring program. Such a program will allow the practitioner to make informed and timely decisions so that the result is an operation that is sustainable and profitable (Table 1).

The reduction of the stocking rate by $40 \%$ and the elimination of the practice of feeding hay in 2001, when the operation was losing $\$ 53$ per acre and $\$ 191$ per cow, changed the financial picture positive by 2003. A 3-year lag period in returns was observed between 2003 and 2005 (\$12 to $\$ 14$ per acre). During this time, pastures presumably recovered from previous managerial abuse that involved other traditional practices such as continuous grazing and overstocking. Between 2006 and 2008, once pastures had improved, net profit was $\$ 40$ to $\$ 45$ per acre and $\$ 226$ to $\$ 252$ per cow. A dramatic decline in average feed costs per cow was realized largely due to the discontinued practice of feeding hay. In 2001 and 2002, the 2 years when hay was last fed, feed costs were $\$ 291$ and $\$ 214$ per cow (55 and $41 \%$ of total business costs, respectively). By 2008, the average feed cost per cow was only $\$ 41$ (mostly from purchase of cottonseed cubes fed during winter), which was largely a reflection of a good balance or match between stocking rate to the available forage supply base.

From 2009 to 2012, we had an unusually wet year (2010), and 3 years with the hardest droughts since the 1950s. The stockpiled forage and the additional leased pastures were the key to our business survival. In the wet year of 2010, we were able to stockpile over 4,000 pounds per acre of forage by October 2010 after pastures had recovered from the 2009 drought. However, with the 2011-2012 drought, we used most of the stockpiled forage and between April 2011 and October 2012; FSC has been between 759 and 2,117 pounds per acre. Moreover, plant vigor was greatly diminished, which triggered our drought recovery plan as previously explained. Body condition scores have been maintained around 5 and weaning weights 
for the period ranged from 540 to 609 pounds. Increased feed costs in 2009 and lease costs in 2010 decreased the profit in those 2 years to $\$ 199$ and $\$ 185$ per cow. However, even with the dramatic drought of 2011 the profit per cow was $\$ 288$. The need to lease additional land to overcome the droughts decreased the profit per acre to $\$ 26, \$ 17$, and $\$ 38$ per acre in 2009,2010 , and 2011, respectively.

At the beginning of fall 2012, the priority was to allow recovery of pastures from the drought by using the limited moisture we received in September 2012. About 50\% of pastures were either vacated or stocking rate was dramatically reduced. Calves were weaned early, and pregnant mother cows moved to new leased pastures (Fig. 2), which will have a negative effect on the profits for 2012. However, maintaining the integrity of the herd is still necessary to reestablish the production cycle after the drought.

\section{Conclusion}

This case study demonstrates the importance of adaptive management to the resilience of a ranch. With a combination of strategic livestock and grazing management, especially adapting the stocking rate to variability in forage production, we were able to increase the grazing capacity and the profitability of the ranch, even during drought.

The ability of practitioners to adapt management practices to achieve specific goals for livestock operations is one of the most valuable assets of the ranch. Managing flexible grazing management programs with proper monitoring allowed us to make informed and timely decisions that largely determined the resilience and profitability of the operation. Surviving droughts and making a profit during the drought involves careful planning and strategies to trigger critical decisions. There might be an opportunity to make additional profit during wet years, but those are much less frequent than dry years.

\section{References}

1. Kothmann, M. 2009. Grazing methods: a viewpoint. Rangelands 31(5):5-10.

2. Bryant, F. C., J. A. Ortega-S., and H. Morales-M. 1998. Planned grazing strategies. In: Proceedings of Management of Grazinglands in Northern Mexico and South Texas. Laredo, TX, USA: Consorcio Tecnico del Noreste de Mexico. p. 69-83.

3. Kothmann, M., R. Teague, H. Díaz-Solís, and W. Grant. 2009. Viewpoint: new approaches and protocols for grazing management research. Rangelands 31(5):31-36.

4. Holechek, J. L., R. D. Pieper, and C. H. Herbel. 1998. Range management: principles and practices. 5th ed. Upper Saddle River, NJ, USA: Prentice Hall. 607 p.

5. González V., E. A., And J. A. Ortega S. 1999. Sistemas de pastoreo y uso adecuado del recurso forrajero. Memorias del Primer Simposium Internacional de Ganadería Tropical Sostenible. Memoria Técnica \#2. INIFAP SAGAR. 68 p.

6. Lukefahr, S. D., J. A. Ortega-S., J. Нohlt, and R. Schmidt. 2010. Grazing management: key for sustainable cattle production in South Texas. Tuli Journal 2010:42-49.

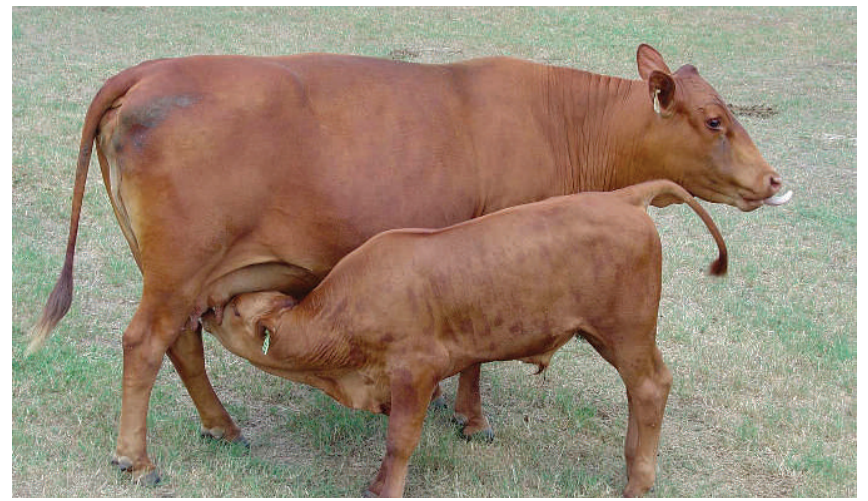

Figure 2. In 2012 calves were weaned early and pregnant mother cows moved to new leased pastures as part of our drought recovery plan.

7. Bryant, F. C. 2009. 2009 was interesting, to say at least. South Texas Wildlife 13(4):4.

8. Ortega-S. J. A., and F. C. Bryant. 2005. Cattle management to enhance wildlife habitat. Kingsville, TX, USA: Caesar Kleberg Wildlife Research Institute, Texas A\&M UniversityKingsville. Management Bulletin No. 6.10 p.

9. Hanselka, C. W., B. J. Ragsdale, and B. S. Rector. 1988. Grazing systems for profitable ranching. College Station, TX, USA:Texas Agricultural Extension Service. Bulletin L-2211. 4 p.

10. Hanselka, W., and F. S. Guthery. 1991. Bobwhite quail management in south Texas. College Station, TX, USA: Texas Cooperative Extension Service, Texas A\&M University. Publication B-5005. 8 p.

11. White, L. D., C. W. Hanselka, and L. Clayton. 1999. Some common grazing management mistakes made by rangeland owners and managers. Risk Management for Texans Series. RLEM No. 2. 2 p.

12. Lyons, R. K., R. V. Machen, and J. W. Stuth. 2000. Forage quality photo guide: evaluating diet quality selected by gazing beef cattle using photographic guidelines. College Station, TX, USA: Texas AgriLife Extension. Publication E541. 2 p.

13. Herd, D. B., And L. R. Sprott. 1986. Body condition, nutrition and reproduction of beef cows. College Station, TX, USA: Texas Agricultural Extension Service. Texas A\&M University. Publication B-1526. 12 p.

14. Grazingland Management Systems, Inc. 1995. Range management and stocking rate practices, 1990-1995, on the Kennedy Memorial Foundation, Sarita, TX, USA. Report in confidential file at the Foundation.

Authors are Professor and Research Scientist, Caesar Kleberg Wildlife Research Institute, Texas A EMM University-Kingsville, Kingsville, TX 78363, USA, poncho.ortega@tamuk.edu(OrtegaS.); Regents Professor, Animal, Rangeland, and Wildlife Sciences Dept, Texas AE'M University-Kingsville, Kingsville, TX 78363, USA (Lukefahr); and Leroy G. Denman, Jr. Endowed Director of Wildlife Research, Caesar Kleberg Wildlife Research Institute, Texas A\&M University-Kingsville, Kingsville, TX 78363, USA (Bryant). 